\title{
Heterotrophic Assimilation and Occurrence of Dissolved Free Amino Acids in a Shallow Estuary
}

\author{
Niels O. G. Jørgensen \\ Institute of Ecology and Genetics, University of Aarhus, NY Munkegade, DK-8000 Aarhus C, Denmark
}

\begin{abstract}
Seasonal changes in concentrations of dissolved free amino acids (DFAA), heterotrophic assimilation of the 5 most abundant free amino acids, and release of DFAA from natural populations of phytoplankton were investigated in a shallow estuary on the east coast of Jutland, Denmark. Maximum DFAA concentrations ( 700 to $900 \mathrm{nM}$; up to $2471 \mathrm{nM}$ was measured) occurred in spring and autumn, lower concentrations (down to $200 \mathrm{nM}$ ) in summer and winter. The occurrence of DFAA was partly reflected in chlorophyll a concentrations. Serine, glutamic acid, glycine, ornithine, and alanine were the 5 dominant free amino acids. Heterotrophic assimilation of these amino acids was determined in 3month intervals at high and low tides, and uptake rates of 0.3 to $23 \mu \mathrm{g} \mathrm{Cl}^{-1} \mathrm{~h}^{-1}$ were measured. Serine was preferentially absorbed by microorganisms. Generally, higher uptake rates were found at low tides than at high tides - apparently due to higher numbers of bacteria at low tide, but also influenced by DFAA concentration. A reduced assimilation rate occurred in winter when both temperature and bacterial densities were low. Mean turnover times of the 5 dominant amino acids ranged from $2 \mathrm{~h}$ in September to $41 \mathrm{~h}$ in December. Primary productivity varied from 2.1 (Mar.) to $21 \mu \mathrm{g} \mathrm{Cl}^{-1} \mathrm{~h}^{-1}$ (Sept.). Heterotrophic assimilation of the 5 amino acids (in terms of carbon) comprised from 10 to $19 \%$ (Sept. and Dec.) and 163 to $238 \%$ (Mar. and Jun.) of the primary productivity, witnessing that phytoplankton primary production could not always have been the main contributor of DFAA in Kysing Fjord. Extracellular organic carbon (EOC) released from natural phytoplankton ranged from 8.1 to $42.0 \%$ of total primary production in situ, and from 15.4 to $27.2 \%$ in the laboratory.

DFAA made up 20.7 to $34.1 \%$ of the EOC in in situ incubations, and 7.3 to $33.0 \%$ in laboratory incubations. Actual amino acid release from phytoplankton was probably overestimated in laboratory incubation due to co-elution of unidentified ${ }^{14} \mathrm{C}$-compounds in chromatographic separations. In situ, the released amino acids constituted $3 \%$ of the total DFAA pool and about $10 \%$ (within the initial $4 \mathrm{~h}$ ) in laboratory incubation. The macrophyte Ulva lactuca also contributed DFAA to the water, but release from the sediment surface appeared to be the major source of DFAA in the water of Kysing Fjord.
\end{abstract}

\section{INTRODUCTION}

The bulk of dissolved organic matter in the sea consists of biological non-degradable matter accumulated over thousands of years (Williams et al., 1969; Menzel and Ryther, 1970). Small organic molecules like amino acids, sugars and organic acids - usually make up less than $10 \%$ of the dissolved organic matter (review by Liebezeit, 1980). Since this low-molecular fraction is an important substrate to microbial heterotrophs, much attention has been paid to the dynamics involved in its formation and utilization. In an estuary, heterotrophic assimilation of dissolved free amino acids was found to equal about $10 \%$ of the primary production in summer (Crawford et al., 1974) and between 1 and $10 \%$ in off shore sea water (Williams et al., 1976).
Natural concentrations of free amino acids range from 100 to $1000 \mathrm{nM}$, with maxima in coastal and estuarine waters (Bohling, 1970; Riley and Segar, 1970; Crawford et al., 1974; Dawson and Gocke, 1978). While the spectrum of free amino acids in sea water varies, generally serine, glycine, lysine, glutamic acid, and ornithine are among the most abundant. Increased concentrations of free amino acids have been observed during periods with high primary production (Wood, 1966; Crawford et al., 1974), suggesting that the amino acids originated as extracellular organic matter released from the phytoplankton. Contrary to this, Bohling (1970) and Riley and Segar (1970) report higher concentrations of free amino acids in the period following a phytoplankton bloom, and William and Yentsch (1976) found that release of dissolved organic matter from natural populations of microalgae could 
not account for the observed heterotrophic uptake of amino acids. Free amino acids have actually been isolated as release products from microalgae. Helleburst (1965) identified amino acids in exudates from several species of phytoplankton algae, and according to Mague et al. (1980) about $7 \%$ of the EOC from a phytoplankton population consisted of free amino acids. The quantitative importance of this amino acid contribution to natural amino acid pools has, however, not been determined.

In the present study, I have recorded the concentrations of the 5 most abundant free amino acids over $16 \mathrm{mo}$, and determined their heterotrophic assimilation at 3-mo intervals in a shallow estuary. In order to trace the sources of the free amino acids, isolation of amino acids in extracellular organic carbon from phytoplankton was performed by high pressure liquid chromatography.

\section{MATERIALS AND METHODS}

\section{Locality and Hydrography}

The studied area, Kysing Fjord, is an estuary of 186 ha situated on the east coast of Jutland (Fig. 1). Water depth averages 0.5 to $0.7 \mathrm{~m}$, but a $1.5 \mathrm{~m}$ deep channel stretches $1 \mathrm{~km}$ into the fjord from the entrance. Tides cause maximum differences in water level height of ca. $20 \mathrm{~cm}$. At the head of the fjord, fresh water enters from Odder River. During low tides most of the fjord has a salinity of less than $10 \% \mathrm{~S}$, but in the bottom layer at the entrance, the average salinity is $15 \%$ S. At high tides inflow of Kattegat water increases the salinity and a 10 to $15 \%$ S tongue heads into the main portion of the estuary at the bottom. According to Muus (1967), salinities of 19 to $23 \%$ S occurred in most of the fjord on 31 August 1956 at both flood and ebb. But in 1963 a sluice was constructed and since then, the water levels have been controlled and the salinity dropped as revealed by measurements in 1980 (Fig. 1).

\section{Sampling Sites}

From March 1980 to July 1981 dissolved free amino acids (DFAA), ammonium, nitrate, and chlorophyll a were measured weekly at Station 1 (Fig. 1); Stations 2 and 3 were occasionally used as reference stations. Station 1 was chosen as a general sampling site because of its mixohaline conditions. At this station mixing of fresh and sea water causes a salinity range from almost fresh water $(1 \% \mathrm{~S})$ to $25 \% \mathrm{~S}$ (Fig. 2). The latter salinity is identical to that outside the fjord entrance. For practical reasons water samples could not always be collected at a specific period in the tidal cycle, e.g. at maximum high or low tides; however, from the salinity of the sampled water, the degree of mixing of sea and fresh water could be determined.

\section{Chemical Analyses}

Water samples for analyses of ammonium, nitrate, phosphate, and chlorophyll a were collected in clean plastic containers. Within $1 \mathrm{~h}$, the water was filtered through glass fiber filters (Whatman GF/C; Whatman, England) and kept at $-20^{\circ} \mathrm{C}$ for later analysis. For chlorophyll a determinations, phytoplankton from 0.5 to 3.01 water was retained on glass fiber filters which were immediately frozen at $-20^{\circ} \mathrm{C}$. Water for analyses of DFAA was filtered in the field through $0.2 \mu \mathrm{m}$ pore size filters (Unipore, USA) using a $60-\mathrm{ml}$ syringe and a Swinnex filter holder (Millipore, USA). Prior to filtration, syringe and filter holder were cleaned in a commercial detergent and rinsed several times in redistilled water. Filtrates were collected in plastic vials which proved to be free of contaminants.

Ammonium, nitrate, and o-phosphate were determined colorimetrically using a Chemlab autoanalyser (Chemlab Instruments, England), according to Solorzano (1969) (ammonium), Wood et al. (1967), (nitrate), and Murphy and Riley (1962) (o-phosphate).

Chlorophyll a was extracted from the glass fiber filters in $90 \%$ acetone for $24 \mathrm{~h}$ in the dark and then quantified according to Lorenzen (1967). Pheophytin a in the extracts was measured after acidification with $1 \mathrm{~N} \mathrm{HCl}$.

Free amino acids were determined as o-phthaldialdehyde derivatives (Merck, FRG) separated by high pressure Iiquid chromatography (HPLC) (Altex Scientific, USA) according to Lindroth and Mopper (1979). The derivatives were then detected by on-line fluorescence (American Instrument Company, USA). The detection limit was $10^{-12}$ mole per amino acid. Proline and hydroxyproline do not react with o-phthaldialdehyde. Individual amino acids were identified by spiking with known amino acids. In addition to usual international abbreviations of amino acids, the following are used: $\alpha$-ABA (aminobutyric acid), $\beta$-ala (alanine), cit (citrulline), orn (ornithine) and tau (taurine).

Water samples were concentrated $10 \times$ by freezedrying prior to analysis of amino acids to improve the signal-to-noise ratio. The increased salt content in the water samples did not interfere with the amino acid analysis, nor did the freeze-drying change the composition or the concentration of the amino acids.

In 2 sets of experiments, released extracellular organic ${ }^{14} \mathrm{Carbon}\left(\mathrm{EO}^{14} \mathrm{C}\right)$ was assayed for free ${ }^{14} \mathrm{C}$ - 


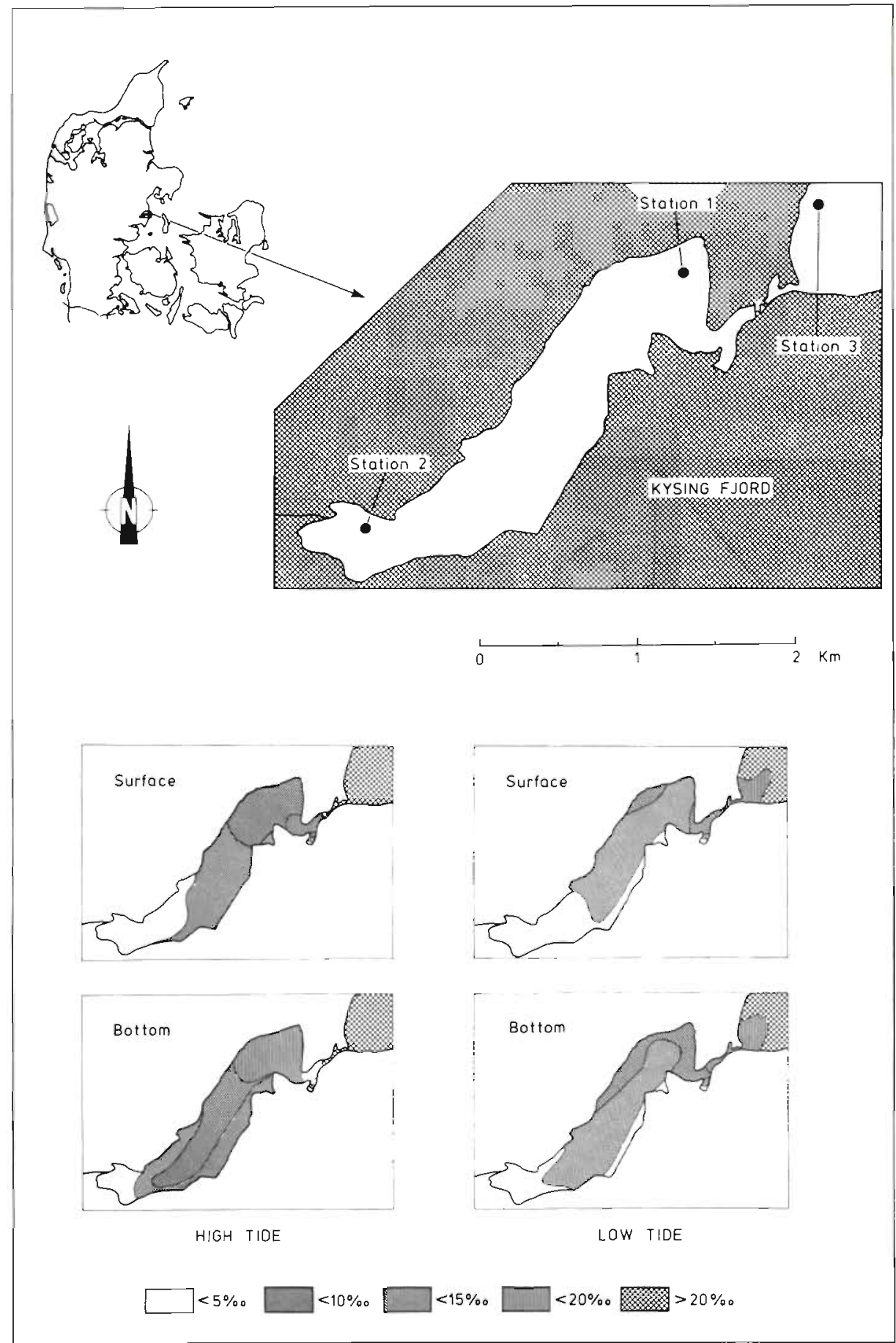

Fig. 1. Location of sampling sites in Kysing Fjord (Denmark). Station 1 was the general sampling locality, while Station 2 (close to the inlet of Odder River) and Station 3 (Kattegat) were used as reference localities. Salinity was measured on 2 September 1980 at 09:00 and 16:00

amino acids. After being quantified fluorometrically, the eluates containing ${ }^{12} \mathrm{C}$ - and ${ }^{14} \mathrm{C}$-amino acids were collected on-line in fractions of $250 \mu \mathrm{l}$ in plastic vials, corresponding to 98 samples in a usual chromatographic run. After addition of a scintillation cocktail, the fractions were counted by liquid scintillation for $20 \mathrm{~min}$. Compounds without a primary amine group were eluted from the column within the first 6 min of the analysis. These compounds included bicarbonate, acetate, glucose, starch, butyric acid, and underivatized amino acids. With an optimum solvent composition for these separations, only aspartic acid was eluted within the initial $6 \mathrm{~min}$ run. The remaining ${ }^{14} \mathrm{C}$ activity was assumed to consist of primary amine derivatives (amino acids).

During fractionation of the EOC, from 85.1 to $98.3 \%$ (mean $93.7 \%$ ) of the radioactivity was recovered. The main portion of the activity was collected in the initial 
24 fractions (0 to $6 \mathrm{~min}$ ). The radioactivity of the remaining 74 fractions ( 6 to $24.5 \mathrm{~min}$ ) ranged from 1.4 to $27 \mathrm{dpm}$ per fraction. Recounting of the samples for 20 min periods showed that the radioactivity could be determined with a standard deviation of $\pm 1.6 \mathrm{dpm}$. Fractions below $1 \mathrm{dpm}$ were not included in the calculations, and radioactive peaks occurring outside known amino acid peaks in the chromatograms were rejected.

\section{Quantification of Bacteria}

Natural concentrations of free and attached bacteria in Kysing Fjord water were determined by using orange direct counts under epifluorescence at $1,000 \times$ magnification (Hobbie et al., 1977).

\section{Microbial Assimilation of Free Amino Acids}

Heterotrophic assimilation of glutamic acid, serine, glycine, alanine, and ornithine was measured at 3-mo intervals at high and low tides. These 5 amino acids were chosen since they were the most abundant DFAA in the water. From 1 to 3 September 1980 they made up an average of $66.1 \%$ of the DFAA pool (glutamic acid $4.1 \%$, serine $18.2 \%$, glycine $12.1 \%$, alanine $6.7 \%$, and ornithine $25.0 \%$ ). The molar composition in December 1980, and in March and June 1981 differed from that found in September 1980 , but the 5 amino acids always accounted for more than $52 \%$ of the total DFAA pool.

Triplicate water samples of $50 \mathrm{ml}$ in clean $50-\mathrm{ml}$ bottles, including a control containing $3 \%$ of formalin, were added $0.01 \mu \mathrm{Ci} \quad(20 \mu \mathrm{l}){ }^{14} \mathrm{C}$-tracer (The Radiochemical Centre, Amersham, England) of each amino acid. The addition of the tracer caused an increase of the natural amino acid concentration of maximum $1 \%$. The bottles were then wrapped in aluminum foil and incubated in situ (samples from September 1980) or placed in the dark in a thermoisolated box at the in situ temperature, brought to the laboratory and then added the tracer. After 20 to 30 min, $20 \mathrm{ml}$ of each sample was filtered through $0.2 \mu \mathrm{m}$ pore size filters, followed by $1 \mathrm{ml}$ of distilled water to rinse the filters. Simultaneously, $20 \mathrm{ml}$ samples for respiration measurements were transferred to vials with $50 \mu \mathrm{l}$ of $10 \mathrm{~N} \mathrm{NaOH}$. Formalin-killed controls were treated similarly. All filters were placed in plastic vials containing $100 \mu \mathrm{l} 1 \mathrm{~N} \mathrm{HCl}$, left overnight, and then radio-assayed by liquid scintillation counting.

The respired fraction of the assimilated ${ }^{14} \mathrm{C}$-amino acids was determined by trapping the $\mathrm{CO}_{2}$ in $8 \mathrm{ml}$ of ethanolamine/ethyleneglycolmonomethyl ether $(1: 7$, $\mathrm{v}: \mathrm{v})$ (Kofoed, 1975). $10 \mathrm{ml}$ of the $\mathrm{NaOH}$-preserved samples were acidified with concentrated $\mathrm{H}_{3} \mathrm{PO}_{4}$ to a $\mathrm{pH}$ of
2.0 and then purged with air for 20 min. Usually $99 \%$ of the radioactivity was trapped in the absorber. Toluene containing $1 \%$ PPO and $0.025 \%$ POPOP (Merck, FRG) was added to the absorber and then the radioactivity was counted. Quenching was corrected using internal and external standards.

\section{Release of DFAA from UIva and Sediment Surface}

Extracellular release of DFAA from the sea lettuce Ulva lactuca L., an abundant macrophyte in Kysing Fjord in summer, was investigated by placing naturally occurring pieces of the alga ( 428 to $615 \mathrm{mg}$ ) into $100-\mathrm{ml}$ Erlenmeyer flasks in untreated or $0.2-\mu \mathrm{m}$ filtered sea water.

Sediment cores of $20 \mathrm{~cm}$ length were taken with acrylic tubes $(4.6 \mathrm{~cm}$ diameter, $25 \mathrm{~cm}$ long) at ca. $40 \mathrm{~cm}$ water depth. The cores were wrapped in aluminum foil up to the sediment surface and $40 \mathrm{ml}$ sea water was gently added on top of the sediment. Flasks with Ulva lactuca and sediment cores were placed in a rack in water at in situ light and temperature. Half of the samples were shaded with aluminum foil to inhibit photosynthesis. Concentrations of DFAA were then followed for $24 \mathrm{~h}$ in the flasks and in the sea water overlying the sediment surface.

\section{Primary Productivity and Release of Extracellular Products}

Primary productivity was measured in clear $50-\mathrm{ml}$ Jena bottles to which 4 or $20 \mu \mathrm{Ci}$ of $\mathrm{H}^{14} \mathrm{CO}_{3}^{-}$was added. Three 'light' and one 'dark' sample per incubation period were then suspended $10 \mathrm{~cm}$ below the water surface in situ. Primary production incubations were started simultaneously with ${ }^{14} \mathrm{C}$-amino acid incubations (Sept.), or $2 \mathrm{~h}$ before start of the amino acid incubation (Dec., Mar, and Jun.); times of the amino acid incubations are shown in Fig. 4. After 2 or 3 h, $20 \mathrm{ml}$ samples were filtered through 3.0 - or $0.2-\mu \mathrm{m}$ filters treated as in the amino acid assimilation experiments. Release of extracellular organic carbon $\left(\mathrm{EO}^{14} \mathrm{C}\right)$ was determined in the 10-ml filtrates. After addition of $1 \mathrm{~N} \mathrm{HCl}$ to give a $\mathrm{pH}$ of 2.0 , the filtrates were bubbled with air for $20 \mathrm{~min}$. The acidified samples were then freeze-dried to remove residual ${ }^{14} \mathrm{CO}_{2}$ (Lancelot, 1979). The filtrates were redissolved in $1-\mathrm{ml}$ redistilled water in an ultrasonic bath and radioassayed. On one occasion, primary production and release of EOC from natural phytoplankton was measured during a $32-\mathrm{h}$ incubation in the Iaboratory. Water samples of $50 \mathrm{ml}$ were added $4 \mu \mathrm{Ci}$ of $\mathrm{H}^{14} \mathrm{CO}_{3}$ and placed in a shaking bath at $12^{\circ}$ at a light intensity of $260 \mu \mathrm{E} \mathrm{m}^{-2} \mathrm{~s}^{-1}$. In the 
laboratory incubation and in the June primary production experiment in situ, the concentrated EOC filtrates were assayed for free ${ }^{14} \mathrm{C}$-amino acids.

\section{RESULTS AND DISCUSSION}

\section{Seasonal Occurrence of DFAA in Kysing Fjord}

The highest concentrations of DFAA in the Kysing Fjord were measured in spring and autumn. The lowest concentrations, from $189 \mathrm{nM}$ to $216 \mathrm{nM}$, occurred in June 1980 and in January 1981 (Fig. 2). In spring and autumn, DFAA concentrations typically increased to 700 to $900 \mathrm{nM}$ levels, but higher concentrations occasionally occurred, e.g. in late September 1980 (1861 nM) and in late March 1981 (2471 nM). From October 1980 the DFAA concentrations were gradually reduced to a period of minimum concentrations in January 1981.

This concentration range falls within concentrations reported from estuarine and true marine waters, but most of the spring and autumn concentrations were higher than previously reported concentrations. Thus, in the Pamlico River estuary, Crawford et al. (1974) measured from 200 to $600 \mathrm{nM}$ of DFAA, and in the York Rive estuary about $350 \mathrm{nM}$ occurred in late summer (Hobbie et al., 1968). In open waters like the Irish Sea and the Baltic Sea, concentrations less than $300 \mathrm{nM}$ have been measured (Riley and Segar, 1970; Dawson and Gocke, 1978).

The spectrum of free amino acids in Kysing Fjord varied, but serine, glutamic acid, glycine, ornithine, and alanine usually made up more than half of the total DFAA pool. Amino acid spectra from 26 September to 24 October 1980 illustrate the observed changes in the composition (Fig. 3). Serine was the most abundant amino acid in about $90 \%$ of the water samples. Glutamic acid prevailed in few samples, e.g. on 3 October 1980 when it made up $29.3 \%$ of the DFAA pool. Ornithine had a more scattered distribution, being common in some samples and occurring in trace amounts in others.

Serine, glutamic acid, glycine, ornithine and alanine are generally reported to be among the most abundant free amino acids in sea water, e.g. in the German Bay (Bohling, 1970), in the Auke Bay, Alaska (Schell, 1974), the Baltic Sea (Dawson and Gocke, 1978), and in the Limf jord, Denmark (Jørgensen et al., 1981a). Ornithine was the dominant free amino acid in the Pamlico River estuary (Crawford et al., 1974). $\beta$-alanine and taurine are usually not reported as common amino acids in sea water, but in the present study they occurred in concentrations above $50 \mathrm{nM}$ in most samples. Like $\alpha$-ABA and citrulline, $\beta$-alanine and taurine have been isolated from marine algae which appear to contain a number of 'unusual' amino acids and their derivatives (reviewed by Fattorusso and Piatelli, 1980)

The occurrence of DFAA was partly reflected in the concentration of chlorophyll a (Fig. 2). In spring 1980 and 1981 and in autumn 1980, the highest chlorophyll a concentrations were generally found, while little chlorophyll a occurred in summer 1980 and in January 1981. The chlorophyll a peak in early April 1981 might have been caused by a phytoplankton bloom. On one occasion, late September 1980, a high DFAA concentration coincided with a chlorophyll a peak. Coincidence of a large primary production and high concentrations of DFAA has previously been observed, e.g. in the Pamlico River estuary during a dinoflagellate bloom (Crawford et al., 1974), and in the York River estuary when a 'red tide' occurred (Wood, 1966). However, in Kysing Fjord the seasonal resemblance in chlorophyll $a$ and DFAA was not only due to excretion of organic compounds from the phytoplankton, as reported below. Dead and decaying algal cells probably also contributed free amino acids to the water. Thus, Bohling (1970) and Riley and Segar (1970) measured enhanced DFAA concentrations after phytoplankton blooms in the German Bay and in the Irish Sea, respectively.

Pheophytin $a$ at Station 1 in Kysing Fjord frequently had a distribution opposite that of chlorophyll a, i.e. being abundant when little chlorophyll a occurred and vice versa (pheophytin concentrations not shown). From March 1980 to July 1981 the concentrations of pheophytin a on the average was $4.3 \pm 3.7$ times higher than the chlorophyll a concentrations. This substantial pheophytin a content may originate from fresh water phytoplankton carried into the fjord from the nutrientrich Odder River, since higher concentrations of chlorophyll a occurred at the head of the fjord than at Stations 1 and 3 (Table 1). Hypothetically, the increasing ionic strength in the middle and outer part of the estuary may be harmful to most of the fresh water algae; these die and subsequently increase the content of dissolved organics in the water. However, the phytoplankton at Station 1 may have other origins, e.g. Kattegat water transported into the fjord, or an occasional high local primary production in periods with little water exchange, e.g. when the sluices are closed. From the present observations it is not possible to determine the exact connection between the occurrence of chlorophyll $a$ and the DFAA.

The spectra of DFAA could not be related to the concentrations of chlorophyll $a$ and thus on primary productivity. A similar observation was made by Wood (1966) during a 'red tide' bloom in the York River estuary. 

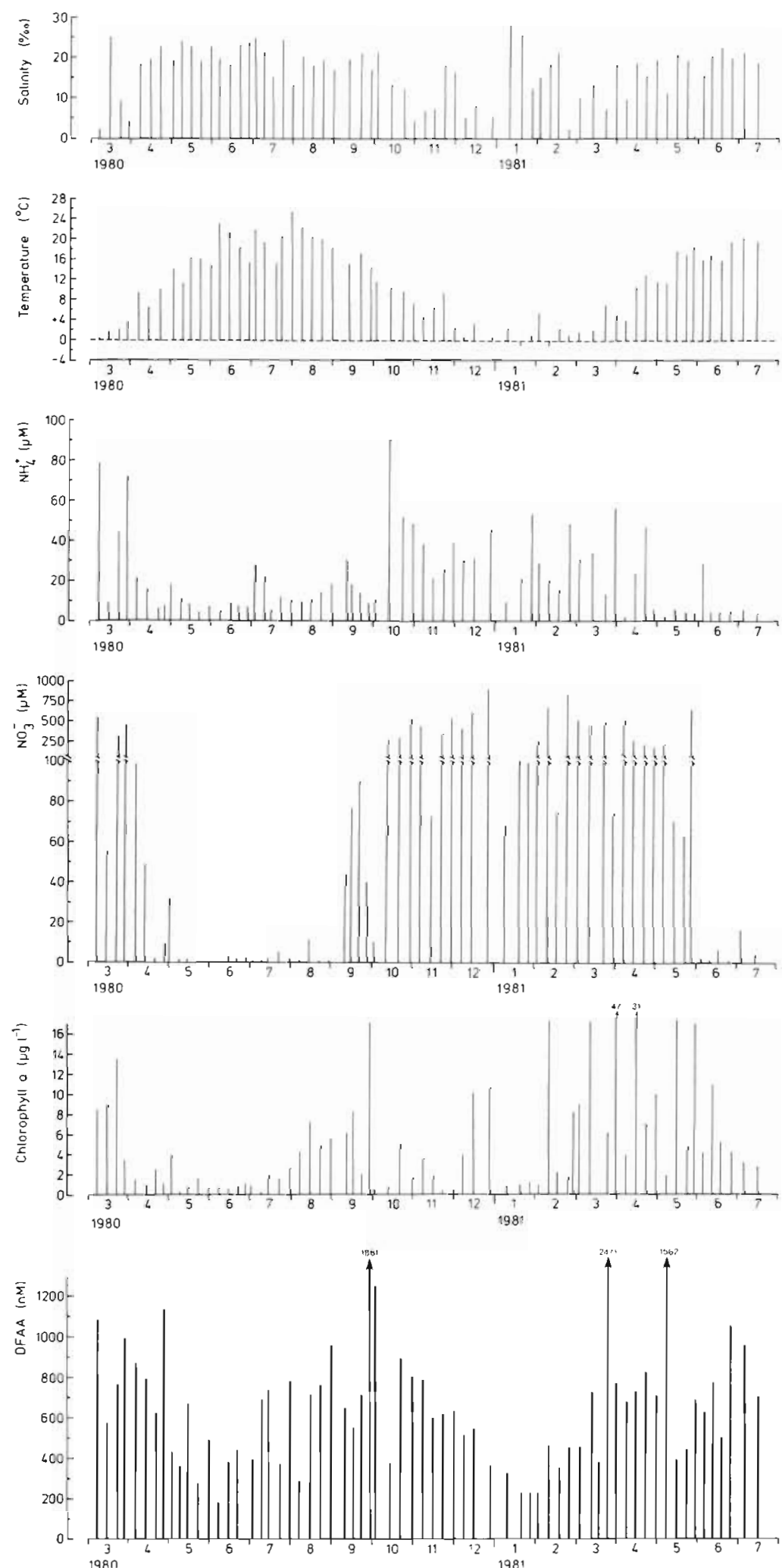

Fig. 2. Salinity, temperature, and concentrations of ammonium, nitrate, chlorophyll $a$, and dissolved free amino acids (DFAA) at Station 1 in Kysing Fjord. Water samples were collected weekly from 8 March 1980 to 14 July 1981

The occurrence of nitrate and ammonium in Kysing Fjord was independent of DFAA concentrations. Most of the ammonium and nitrate was probably transported into the Fjord from Odder River; at least this was true of nitrate in winter and spring since large amounts of nitrate occurred in both river and fjord, but not in 

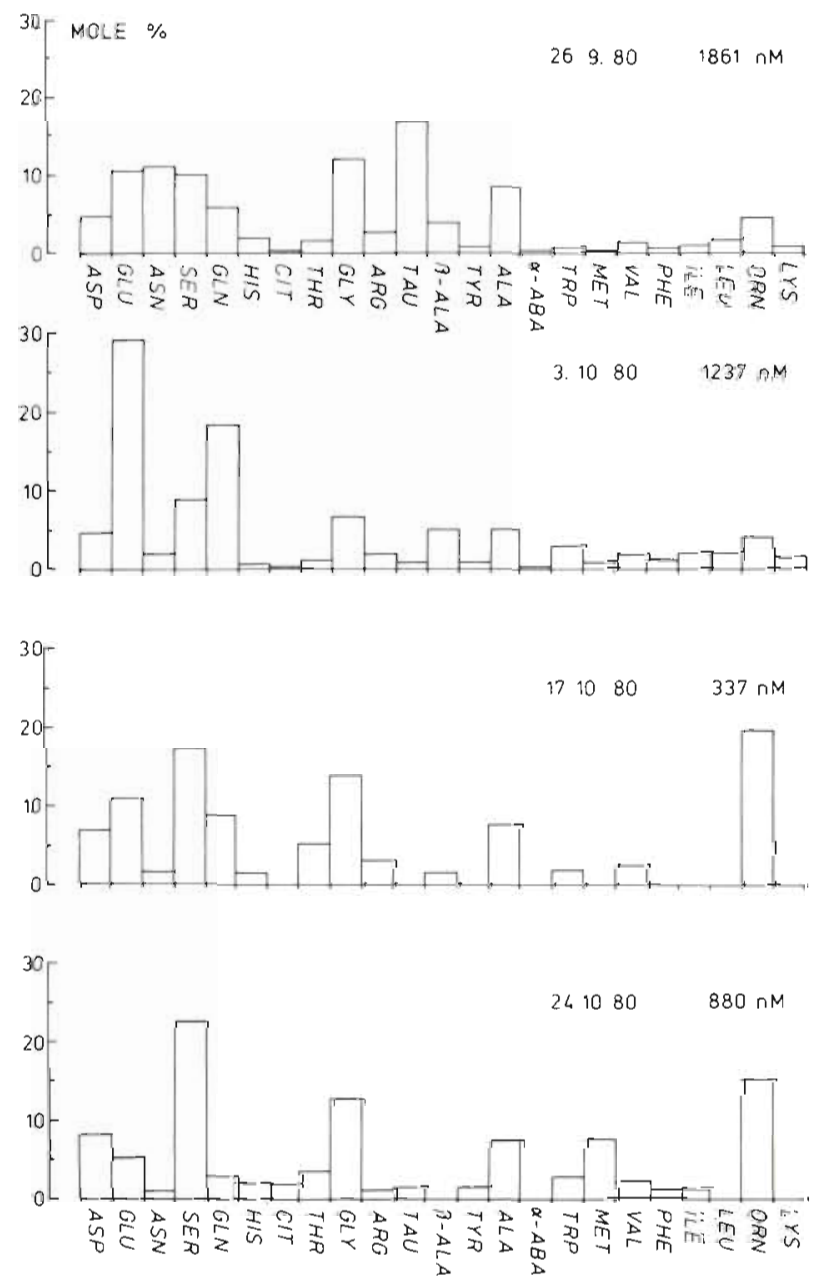

Fig. 3. DFAA spectra in 4 water samples, autumn 1980. Amino acids shown in the chromatographic elution order

Kattegat (own unpubl. results). When the salinity at Station 1 is compared with the concentrations of ammonia and nitrate, it appears that their variations outside summer periods mostly were related to the degree of mixing of inflowing sea water and fresh water from the river. The importance of this mixing on the DFAA at Station 1 was investigated on 3 occasions.
DFAA concentrations in water samples collected at various salinities inside and outside the fjord showed that free amino acids at Station 1 could not be explained by a simple mixing of sea and fresh water (Table 1). Thus, on 3 June 1981 the DFAA concentration at Station 1 was higher than that at Stations 2 and 3 , but on 16 June, the lowest concentration was recorded at Station 1. An intermediate concentration at Station 1 only occurred on $26 \mathrm{May}$. The amino acid spectra on 26 May and 3 June were rather similar at all 3 stations, with serine, glycine and ornithine the most abundant (not shown). On 16 June, when a high salinity $(17 \% \mathrm{~S})$ occurred, at Station 2 the amino acid composition significantly differed from that at Stations 1 and 3 . Glutamic acid and glutamate made up $54 \%$ of the DFAA pool, while these amino acids amounted to less than $16 \%$ at Stations 1 and 3. Salinities indicate that the water at Station 1 was mainly incoming sea water. This probably explains its low chlorophyll a content as compared with the concentrations of 41 to $51 \mu \mathrm{g} \mathrm{l}^{-1}$ at Station 2. Nitrate concentrations appeared mainly to depend on the dilution of water from Odder River, while no trends were evident in the ammonia and phosphate concentrations.

\section{Heterotrophic Assimilation of DFAA}

Changes in heterotrophic assimilation (incorporation and respiration) of glutamic acid, serine, glycine, alanine and ornithine were related to the tide level; generally, maximum assimilation occurred during low tides (Fig. 4). From 1 to 3 September 1980, assimilation of these 5 amino acids ranged from 20 to $300 \mathrm{nmol}$ $1^{-1} h^{-1}$, or 1 to $15 \mu \mathrm{g} \mathrm{Cl} l^{-1} h^{-1}$. Maximum rate was measured at midnight 1 September and this coincided with a high amino acid concentration (1,307 $\mathrm{nM}$ ) and an usual low water depth of about $8 \mathrm{~cm}$ at Station 1. In the same period in September, the lowest rates of 1 to $2 \mu \mathrm{g} \mathrm{Cl} \mathrm{C}^{-1} \mathrm{~h}^{-1}$ were measured at a high water depth and a high salinity, except on 1 September at 14.00 and 19.00. This latter discrepancy was probably due to

Table 1. Salinity and concentrations of inorganic nutrients, dissolved free amino acids (DFAA), and chlorophyll a at 3 sampling dates in Kysing Fjord 1981. Positions of Stations 1 to 3 are show in Fig. 1

\begin{tabular}{|c|c|c|c|c|c|c|c|c|c|c|}
\hline \multirow[b]{2}{*}{ Factors } & & \multicolumn{3}{|c|}{ Station 3} & \multicolumn{3}{|c|}{ Station 1} & \multicolumn{3}{|c|}{ Station 2} \\
\hline & & 26.5 & 3.6 & 16.6 & 26.5 & 3.6 & 16.6 & 26.5 & 3.6 & 16.6 \\
\hline Salinity & $(\%)$ & 22 & 23 & 25 & 18 & 19 & 23 & 0.4 & 0.9 & 17 \\
\hline $\mathrm{NH}_{4}^{+}$ & $(\mu \mathrm{M})$ & 3 & 7 & 2 & 3 & 28 & 3 & 29 & 4 & 3 \\
\hline $\mathrm{NO}_{3}^{-}$ & $(\mu \mathrm{M})$ & 1 & 5 & 1 & 62 & 8 & 1 & 337 & 673 & 69 \\
\hline $\mathrm{o}-\mathrm{PO}_{4}^{3-}$ & $(\mu \mathrm{M})$ & 2 & 1 & 3 & 6 & 3 & 2 & 4 & 1 & 4 \\
\hline DFAA & $(n M)$ & 904 & 876 & 689 & 682 & 964 & 490 & 551 & 620 & 1991 \\
\hline Chlorophyll a & $\left(\mu \mathrm{g} \mathrm{l}^{-1}\right)$ & 4 & 4 & 3 & 5 & 3 & 5 & 41 & 54 & 45 \\
\hline
\end{tabular}



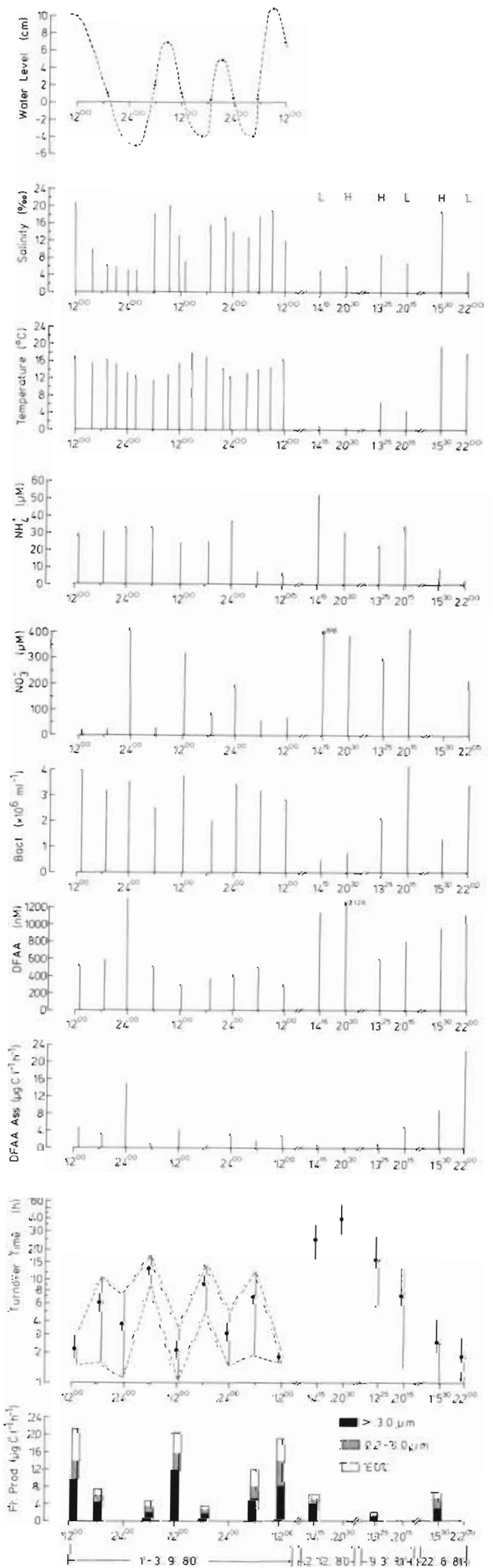

severe impounding caused by a western gale which inhibited a regular tidal cycle for several days prior to the investigation period. In December 1980 and in March and June 1981, the highest uptake rates occurred at low tides. The amino acid assimilation increased from 0.3 to $0.9 \mu \mathrm{g} \mathrm{Cl}^{-1} \mathrm{~h}^{-1}$ in December 1980 , to 1.5 to $5.4 \mu \mathrm{g} \mathrm{Cl}^{-1} \mathrm{~h}^{-1}$ in March and 9.2 to $23.1 \mu \mathrm{g} \mathrm{Cl}{ }^{-1} \mathrm{~h}^{-1}$ in June 1981 at high and low tide, respectively.

Assimilation rates were influenced by the number of bacteria, DFAA concentration, and temperature. Bacterial densities of 1.5 to $4.0 \times 10^{6} \mathrm{ml}^{-1}$ occurred at most of the sampling times, but in December 1980 below $0.8 \times 10^{6}$ bacteria $\mathrm{ml}^{-1}$ were found. In September 1980 , high assimilation rates were generally reflected in high bacterial numbers, but uptake rate increased when a high amino acid pool was available to the bacteria. This occurred at midnight 1 September when an assimilation rate of $15 \mu \mathrm{g} \mathrm{Cl} \mathrm{Cl}^{-1} \mathrm{~h}^{-1}$ was measured. The opposite situation, i.e. low bacterial density and low amino acid concentration, occurred at 2 September 19.00 when the uptake rate was reduced to $1 \mu \mathrm{g}$ $\mathrm{Cl}^{-1} \mathrm{~h}^{-1}$. In December 1980 assimilation rate was probably affected by both low temperature and few bacteria, since a high amino acid concentration coincided with an assimilation rate of only $0.3 \mu \mathrm{g} \mathrm{Cl}^{-1} \mathrm{~h}^{-1}$ at high tide. At low tide, however, assimilation was 3 times higher though both DFAA concentration and bacterial numbers were reduced. The increase in assimilation rates from March to June 1981 was probably due to increased temperature, since comparable amino acid concentrations and bacterial numbers occurred at both high and low tide, respectively. Contrary to the assimilation in September (except on 1 September at midnight) maximum assimilation occurred simultaneously with high concentrations of amino acids in December 1980 and March and June 1981.

In addition to temperature, the similarity in assimilation rates and abundance of bacteria suggests that the number of bacteria rather than the concentration of free amino acids determined the amino acid assimilation in Kysing Fjord. Other conditions may, however, also influence bacterial assimilation. Among these is adaption to low temperatures as observed in Antarctic bacterioplankton (Hodson et al., 1981).

The frequently observed coincidence of low tides and high bacterial densities was probably caused by

Fig. 4. Concentrations of total DFAA, assimilation and turnover time of glutamic acid, serine, glycine, alanine, and ornithine at low tides (L) and high tides $(\mathrm{H})$ in September and December 1980, and March and June 1981. In addition, changes in water level (1-3 September 1980), salinity, concentration of ammonium, nitrate, and bacteria, and cumulative primary productivity are shown. Assimilation of the 5 amino acids expressed as mean rates, their turnover time as means $\pm 1 \mathrm{~S} . \mathrm{D}$. Primary productivity was measured over $2 \mathrm{~h}$; average rates of each fraction are shown. Locality: Station 1 
transport of bacteria-rich fresh water from Odder River into the fjord. Thus, the number of bacteria in Odder River was determined on 2 occasions in May 1981 to be 5.9 and $7.1 \times 10^{6} \mathrm{ml}^{-1}$, relative to the maximum of about $4.0 \times 10^{6} \mathrm{ml}^{-1}$ at Station 1 in Kysing Fjord. Most fresh water and terrestrial bacteria also grow well in sea water (MacLeod, 1971).

Individual assimilation rates of the 5 amino acids varied, but serine was typically absorbed at the highest rates. Thus, serine assimilation on average made up $49 \%$ of the uptake of the 5 amino acids in September 1980 .

A portion of the assimilated amino acids was used as source of energy by microorganisms, as from 30 to $70 \%$ of the amino acid carbon was respired. A substantial proportion of glutamic acid usually was respired, typically 60 to $65 \%$, but in June 1981 up to $73 \%$ was measured. Contrary to this were ornithine and alanine with only 30 to $40 \%$ respired. Intermediate respiration rates were measured for serine and glycine. A high respiration of glutamic acid was also measured in the Pamlico River estuary by Crawford et al. (1974); however, generally a larger portion of the amino acids was respired in Kysing Fjord than reported from other marine areas (Williams et al., 1976; Dawson and Gocke, 1978). This does not seem to arise from a systematic or analytical error, since $\mathrm{H}^{14} \mathrm{CO}_{3}^{-}$controls were used routinely.

Crawford et al. (1974) suggested that the high occurrence of ornithine in the Pamlico River estuary was caused by inability of the microorganisms to absorb this amino acid. This appears not to be true as ornithine in Kysing Fjord was assimilated at rates similar to those of alanine.

The mean turnover time of the 5 amino acids ranged from $2 \mathrm{~h}$ in September 1980 to $41 \mathrm{~h}$ in December 1980 (Fig. 4). The shortest turnover time occurred for serine in September (1.1 h) and for glutamic acid in June 1981 (46 min). Glycine and ornithine in December had the longest turnover times measured, 62 and $59 \mathrm{~h}$, respectively.

Present amino acid assimilation rates of 0.3 to $23 \mu \mathrm{g}$ $\mathrm{Cl}^{-1} \mathrm{~h}^{-1}$ are within the range of assimilation measured in Pamlico River estuary, but they are larger than those determined for the Baltic Sea (Dawson and Gocke, 1978) and off the Californian coast (Williams et al., 1976). As in the present study, serine was the major assimilated amino acid.

The observed bacterial densities of 0.7 to $4.0 \times 10^{6}$ $\mathrm{ml}^{-1}$ in Kysing Fjord correspond to 7 to $40 \mu \mathrm{g} \mathrm{Cl}^{-1}$, assuming a bacterial cell volume of $0.06 \mu \mathrm{m}^{3}$, a density of $1.1 \mathrm{~g} \mathrm{~cm}^{-3}$, and a C-\% of 15 (wet wt) (Hagström et al., 1979). If free amino acids were the only carbon source of the bacteria, the hypothetical turnover time of the bacterial carbon would be $7 \mathrm{~h}$ (Sept.), $12 \mathrm{~h}$ (Dec.),
$9 \mathrm{~h}$ (Mar.), and $1.4 \mathrm{~h}$ (Jun.). Average turnover times of amino acids were $5.5 \mathrm{~h}, 34 \mathrm{~h}, 12 \mathrm{~h}$, and $2.2 \mathrm{~h}$, respectively. Thus, the hypothetical turnover of the bacteria carbon exclusively from amino acid carbon on the average made up $58 \%$ of the amino acid carbon turnover. The discrepancy in the September rate which suggests that more amino acid carbon was assimilated than the bacterial carbon could account for, is not necessarily erroneous as the turnover time may not be representative of all the free amino acids in the water.

The use of tracers in the present type of studies may under- or overestimate actual heterotrophic assimilation if the following conditions are not observed: (1) duration of incubation should be kept at a minimum to prevent changes in the microbial community; (2) during incubation, the concentration of the substance investigated should not be significantly reduced and new substances should not be added; (3) the radioactive label should be identical to the total, chemically determined pool of the specific substance. Point (1) may not always have been fulfilled in the determination of the amino acid assimilation in Kysing Fjord, since the short doubling time of the bacteria in periods with a high heterotrophic activity might have caused some changes in the microbial community. The second point was probably never met as no short-term variations in amino acid concentrations were observed within the incubation period (own unpubl. result), indicating a balance between assimilation and production of the amino acids, lasting for at least $30 \mathrm{~min}$. The latter circumstance caused an underestimation of assimilation due to the relative depletion of radioactive label. Since the underestimation increases with bacterial activity, this error mainly prevailed in the incubations in summer. Point (3) may not always be kept in studies of dissolved organic matter, as suggested by Dawson and Gocke (1978) and Gocke et al. (1981) who measured the microbial assimilation of free amino acids and glucose, respectively, in the Baltic Sea. In both cases they found that the prevalent microbial populations were insufficient to account for the substrate uptake measured. They suggested that only a portion of the dissolved organics was free and available to the organisms, or that the radioactive labelling was not representative of the total free substrate pool. Summarizing possible errors in the present study, Point (2) might have underestimated, point (3) overestimated actual assimilation rates. The effect of (1) was probably of minor importance.

The above estimated seasonal turnover times of both amino acids and bacteria in Kysing Fjord appear, however, to be reasonable as compared with the doubling time of 10 to $100 \mathrm{~h}$ for pelagic bacteria in the Baltic Sea (Hagström et al., 1979). Since Kysing Fjord is a considerably richer environment (higher bacterial densities, 
higher DFAA concentrations [Dawson and Gocke, 1978], and higher temperatures) than the Baltic Sea, a larger activity is expected to occur in Kysing Fjord.

The quantitative significance of the apparently unchanged substrate concentrations during the incubations (2) and a possible nonrepresentative ${ }^{14} \mathrm{C}$-labelling of the amino acids (3) is unknown; it might have been of importance in June and September measurements.

Assimilation of free amino acids was quantitatively important in the carbon cycling in Kysing Fjord as compared with primary production. The photosynthetically C-fixation ranged from up to $21 \mu \mathrm{g} \mathrm{Cl} \mathrm{Cl}^{-1} \mathrm{~h}^{-1}$ in September 1980 , to 2.1 to $6.5 \mu \mathrm{g} \mathrm{Cl} l^{-1} \mathrm{~h}^{-1}$ in December 1980, and in March and June 1981 (Fig. 4). From 20 to $36 \%$ of the C-fixation was measured in the $0.2-$ to 3.0 $\mu \mathrm{m}$ fraction (see below). Assuming that the 5 amino acids, which on average made up $60 \%$ of the DFAA pools, constituted a similar proportion of the total DFAA assimilation, the observed assimilation equalled (in terms of carbon) 33\% (Sept.), $17 \%$ (Dec.), $271 \%$ (Mar.), and 396\% (Jun.) of the photosynthetic rate. These values, especially in March and June, are higher than similar reported rates. Thus, Crawford et al. (1974) and Williams et al. (1976) found that the amino acid uptake amounted to up to $10 \%$ of the photosynthetic C-fixation. In Kysing Fjord, the primary production measured in March and June 1981 may not be representative to the actual spring production. Alternatively, the phytoplankton primary production may not be a major source of DFAA in the estuary.

\section{SOURCES OF DFAA}

\section{Release of EOC and DFAA from Phytoplankton}

During phytoplankton primary production measurement in Kysing Fjord in June 1981, from $8.1 \%(8 \mathrm{~h})$ to $42.0 \%$ ( $1 \mathrm{~h}$ ) of the fixed carbon was lost as extracellular organic carbon $\left(\mathrm{EO}^{14} \mathrm{C}\right.$ ) (Fig. 5A). Within the initial 2-h incubation, elevated $C$-fixation was measured in the 0.2 - to $3.0-\mu \mathrm{m}$ fraction than in the $>3.0-\mu \mathrm{m}$.

In long-term incubation in the laboratory, release of $E \mathrm{O}^{14} \mathrm{C}$ from a natural phytoplankton population accounted for $15.4 \%(14 \mathrm{~h})$ to $27.2 \%$ (2 h) of the total photosynthetic C-fixation (Fig, 6A). During the $10 \mathrm{~h}$ dark incubation, total ${ }^{14} \mathrm{C}$-activity decreased by $22 \%$, but $15 \%$ of the fixed carbon still occurred as $\mathrm{EO}^{14} \mathrm{C}$.

In both experiments, the $\mathrm{EO}^{14} \mathrm{C}$ release rates are in agreement with rates measured in open waters, e.g. by Lancelot (1979; Southern North Sea), Williams and Yentsch (1976; coastal subtropical sea), but somewhat larger than rates reported from more eutrophic waters, such as a Georgian estuary (Thomas, 1971), and Booth
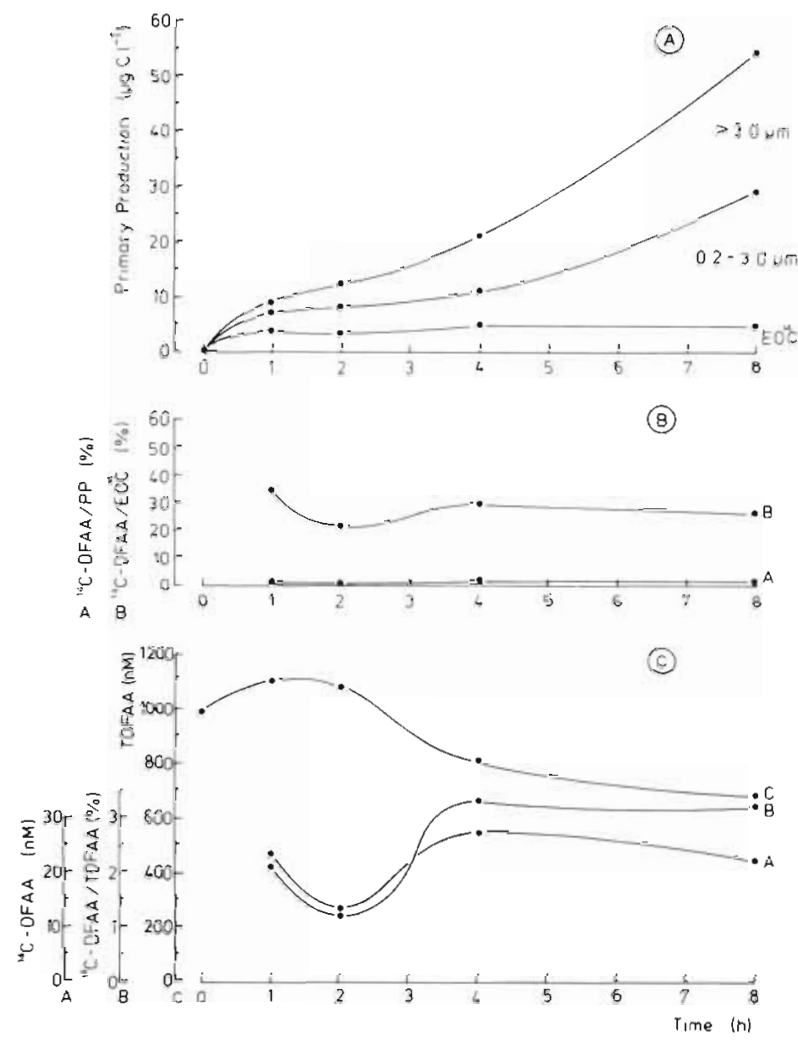

Fig. 5. Primary production measured in situ at Station 1 on 22 June 198010.00 to 18.00 (A). Fixed carbon was separated in $>3.0-\mu \mathrm{m}$ and $>0.2-$ and $<3.0-\mu \mathrm{m}$ fractions, and as extracellular organic carbon $(E O C,<0.2-\mu \mathrm{m})$; cumulative values for each fraction. (B) Percentage of ${ }^{14} \mathrm{C}$-DFAA of total primary production (Curve A) and of EOC (Curve B). (C) Concentrations of ${ }^{14} \mathrm{C}$-DFAA (Curve A), percentage of ${ }^{14} \mathrm{C}$-DFAA of total DFAA (TDFAA) (Curve B), and TDFAA concentrations in incubation bottles (Curve $C$ ). All values are means of at least 2 measurements

Bay Harbor (Mague et al., 1980). A relative reduction of $\mathrm{EO}^{14} \mathrm{C}$ with increasing incubation time was also observed by Nalewajko et al. (1976) in natural phytoplankton communities, but not in axenic cultures, suggesting that bacteria were responsible for the EOC reduction. When long incubation periods are used, bacterial assimilation may increase due to growth of bacteria on the walls of the incubation flasks. This may explain the $\mathrm{EO}^{14} \mathrm{C}$ decrease by 8 and $14 \mathrm{~h}$, whereas the increase by 24 and $32 \mathrm{~h}$ might have been caused by accumulation of larger molecules, as discussed later.

Originally, separation of particulate matter in the $>3.0-$ and $>0.2-\mu \mathrm{m}$ fractions was made to segregate phytoplankton from bacteria. According to Larson and Hagström (1979), the radioactivity in the $0.2-$ to $3.0-\mu \mathrm{m}$ fraction in $\mathrm{H}^{14} \mathrm{CO}_{3}$ incubations of natural marine phytoplankton consists of bacterial assimilated $\mathrm{EO}^{14} \mathrm{C}$. This was not so in the present study; here, the total radioactivity in this fraction and in the $\mathrm{EO}^{14} \mathrm{C}$ typically exceeded that of the $>3.0-\mu \mathrm{m}$ fraction. The amount of 


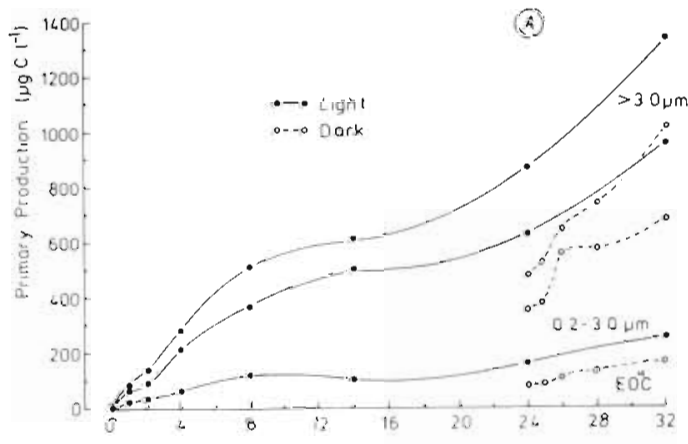

(3)

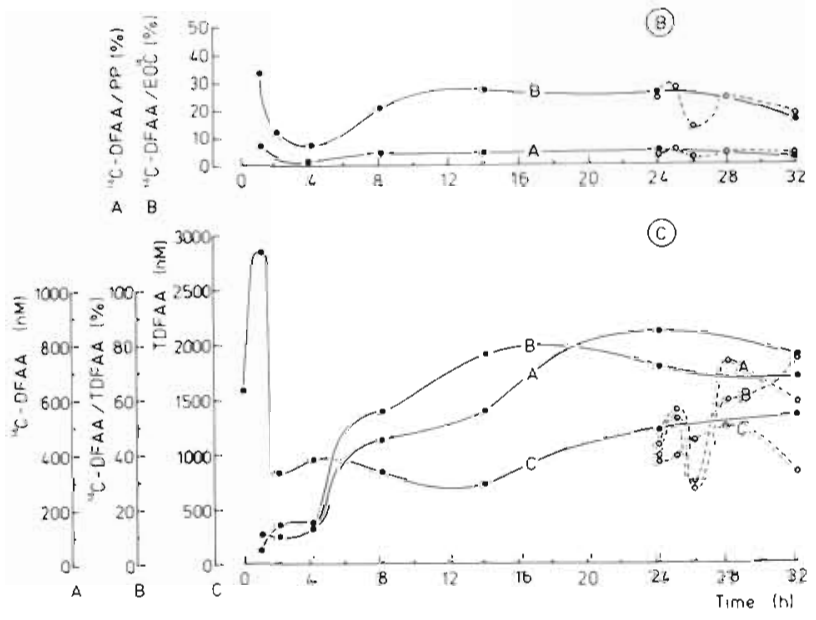

Fig. 6. Primary production measured in the laboratory at $12{ }^{\circ} \mathrm{C}$ and $260 \mu \mathrm{E} \mathrm{m} \mathrm{m}^{-2} \mathrm{~s}^{-1}$. Water for incubation was collected at Station 2 in Kysing Fjord on 5 May 1981. After $14 \mathrm{~h}$ of lightincubation, half the samples were dark-incubated for $10 \mathrm{~h}$, and then re-incubated in light. For details consult legend to Fig. 5. Chlorophyll a concentration: $96 \mu \mathrm{g} \mathrm{I}^{-1}$; number of bacteria: $4.3 \times 10^{6} \mathrm{ml}^{-1} ; 8 \% \mathrm{~S}$

EO ${ }^{14} \mathrm{C}$ being assimilated by bacteria in the in situ and in the laboratory experiment during the incubation cannot be determined. The measured release rates of EOC and EOC products (see below) must therefore be considered as net rates.

In the in situ experiment, the proportion of the $\mathrm{EO}^{14} \mathrm{C}$ identified as ${ }^{14} \mathrm{C}$-DFAA varied from 20.7 to $34.1 \%$ (Fig. $5 \mathrm{~B})$. The carbon of the ${ }^{14} \mathrm{C}$-DFAA made up a maximum of $2 \%$ of the total C-fixation. From the primary production rate, amino acid release rates from phytoplankton were 1.1 to $1.2 \mu \mathrm{g} \mathrm{Cl} \mathrm{Cl}^{-1} \mathrm{~h}^{-1}$. Released ${ }^{14} \mathrm{C}$-DFAA amounted to 1.5 to $3.3 \%$ of the total DFAA (TDFAA) pool in the water (Fig. 5C), determined from Fig. 5A and $\mathrm{B}$, and using an MW of 110 and $\mathrm{a}$ C- $\%$ of 46 of the amino acids. TDFAA concentrations varied from $1.096 \mathrm{nM}(1 \mathrm{~h})$ to $679 \mathrm{nM}(8 \mathrm{~h})$, and ${ }^{14} \mathrm{C}$-DFAA concentrations ranged from $13 \mathrm{nM}(2 \mathrm{~h})$ to $27 \mathrm{nM}(4 \mathrm{~h})$. After $4 \mathrm{~h}$, the ${ }^{14} \mathrm{C}$-DFAA made up a rather stable fraction of the TDFAA of about $3 \%$.

In the laboratory experiment, the ${ }^{14} \mathrm{C}$-DFAA usually amounted to more than $20 \%$ of the $\mathrm{EO}^{14} \mathrm{C}$ release (Fig. $6 \mathrm{~B})$. The ${ }^{14} \mathrm{C}$-DFAA fraction of the $\mathrm{EO}^{14} \mathrm{C}$ initially con- stituted from $7.3 \%(4 \mathrm{~h})$ to $33 \%(1 \mathrm{~h}) ;$ when the incubation period increased, $26 \%(14 \mathrm{~h})$ and $16 \%(32 \mathrm{~h})$ of the EO ${ }^{14} \mathrm{C}$ was recovered as ${ }^{14} \mathrm{C}$-DFAA. A similar ${ }^{14} \mathrm{C}-$ DFAA proportion was found during dark incubation, but a decrease occurred after $2 \mathrm{~h}$ of renewed photosynthesis. Within the initial $4 \mathrm{~h}$ period, 11 to $13 \%$ of the TDFAA pool originated from the $\mathrm{EO}^{14} \mathrm{C}$, but then the fraction increased to a maximum of $76 \%$ by $14 \mathrm{~h}$ (Fig. $6 \mathrm{C}$ ). After $10 \mathrm{~h}$ of darkness, the ${ }^{14} \mathrm{C}$-DFAA was reduced from 76 to $42 \%$ of the TDFAA. At the same time, TDFAA concentrations had increased in both dark and light samples. The peak measured in TDFAA by $1 \mathrm{~h}$ of incubation might have been due to contamination.

The ${ }^{14} \mathrm{C}$-DFAA need not exclusively reflect a high amino acid net release rate; they may also be caused by autolysis and degradation of recently dead algal cells. This may especially have been true of the $32 \mathrm{~h}$ laboratory incubation. The measured release of free amino acid in both experiments can be checked since amino acid assimilation and turnover time of the total DFAA pool can be calculated from the production of the ${ }^{14} \mathrm{C}$-amino acids and the total DFAA pool. In the in situ experiment (Fig. 5), the ${ }^{14} \mathrm{C}-\mathrm{DFAA} / \mathrm{EO}^{14} \mathrm{C}$ and the ${ }^{14} \mathrm{C}$-DFAA/TDFAA ratios had steady state levels from 4 to $8 \mathrm{~h}$ of incubation. Within this period, assimilation of DFAA was calculated to $160 \mathrm{nmol} 1^{-1} \mathrm{~h}^{-1}$, corresponding to a turnover time of $4.4 \mathrm{~h}$. This is in reasonable agreement with the observed turnover time of 1.1 to $4.2 \mathrm{~h}$ (Fig. 4). As compared with the primary productivity of $6.5 \mu \mathrm{g} \mathrm{Cl}^{-1} \mathrm{~h}^{-1}$, amino acid assimilation was large and could obviously not have been supported by the phytoplankton primary production for longer periods of time. This may partly explain the observed reduction in TDFAA concentrations (Fig 5).

Similar calculations for long-term laboratory incubations are more difficult to make since no plateaus occurred similtaneously in Fig. $6 \mathrm{~B}$ and $\mathrm{C}$, but rates may be estimated. From the 2 to $4 \mathrm{~h}$ and the 14 to $24 \mathrm{~h}$ incubations in the light, amino acid assimilation was estimated to be 208 and $44 \mathrm{nmol} \mathrm{l}^{-1} \mathrm{~h}^{-1}$, and turnover times to be 4.3 and $21.8 \mathrm{~h}$, respectively. In terms of carbon, these uptake rates appear reasonable as compared with the primary production of $63 \mu \mathrm{g} \mathrm{Cl}^{-1} \mathrm{~h}^{-1}$. The turnover time of $21.8 \mathrm{~h}$ from 14 to $24 \mathrm{~h}$ seems, however, unrealistic long relative to the high concentration of DFAA and the large number of bacteria in the water (see caption to Fig. 6). This suggests that the measured ${ }^{14} \mathrm{C}$-DFAA fraction of the $\mathrm{EO}^{14} \mathrm{C}$ was overestimated during the long incubation period. A possible overestimation of the ${ }^{14} \mathrm{C}$-DFAA may have arisen from a chromatographic co-elution of individual, free amino acids with ${ }^{14} \mathrm{C}$-non-DFAA such as proteinaceous matter and larger organic molecules containing primary amine groups. If so, the course of the ${ }^{14} \mathrm{C}$-DFAA/ TDFAA curve in Fig. 6C may illustrate: (1) a steady 
state period from 2 to $4 \mathrm{~h}$ reflecting equal uptake and assimilation rates of the amino acids, and (2) an increase phase in which larger molecules accumulate, either from algal release or from lysis and degradation of dead cells. Thus, the measured ${ }^{14} \mathrm{C}$-DFAA/EO ${ }^{14} \mathrm{C}$ ratio of $7.3 \%$ by $4 \mathrm{~h}$ may represent the free amino acid contribution from the EOC under steady state conditions. This is less than the ${ }^{14} \mathrm{C}-\mathrm{DFAA} / \mathrm{EO}^{14} \mathrm{C}$ contribution of 25 to $29 \%$ in the in situ experiment. However. both rates may be true since phytoplankton in the 2 incubations differed in productivity. Age of the population and physiological conditions of individual algal cells probably also influence the release of EOC and thus of amino acids. The rate of $7.3 \%$ in the long-term incubation agrees with Mague et al. (1980) who report that $7.1 \%$ of the EOC from a natural phytoplankton population was identified as DFAA. Separation of EOC was also performed by Helleburst (1965); he concluded that 'Considerable quantities of amino acids and peptides were also detected as excretory products of the algae'.

In laboratory incubation, the ${ }^{14} \mathrm{C}$-DFAA proportion of the $\mathrm{EO}^{14} \mathrm{C}$ decreased by $4 \mathrm{~h}$, and after $2 \mathrm{~h}$ of renewed photosynthesis in the dark-incubated samples (Fig. $6 \mathrm{~B})$. The decrease in the ${ }^{14} \mathrm{C}-\mathrm{DFAA}$ coincided with an increase in activity of the 0.2 - to $3.0-\mu \mathrm{m}$ fraction, suggesting bacterial uptake of the released amino acids. The 2 and $4 \mathrm{~h}$ delay in the reduction of the ${ }^{14} \mathrm{C}-\mathrm{DFAA}$ may thus reflect a lag phase in the bacterial assimilation of the newly photosynthesized, released DFAA. Since the phytoplankton was kept in dim light prior to the experiment, the initial phase was comparable to the period following dark incubation. However, a decrease in ${ }^{14} \mathrm{C}$-DFAA/EO ${ }^{14} \mathrm{C}$ also occurred in the in situ experiment (Fig. 5B), though a lag phase in the possible assimilation of the ${ }^{14} \mathrm{C}$-DFAA should not be expected in these incubations, since the phytoplankton was constantly illuminated. The cause of the observed decrease in ${ }^{14} \mathrm{C}$-DFAA in situ therefore is uncertain.

Changes in the TDFAA and the ${ }^{14} \mathrm{C}$-DFAA spectra occurred in both the incubations, but no trends were apparent. The main portion of the TDFAA consisted of glutamic acid, glycine, and serine, while the predominant ${ }^{14} \mathrm{C}$-amino acids were glutamic acid, serine, and glutamate.

Glycine, serine, glutamate, but not glutamic acid, are among the initially photosynthesized amino acids in various cultures of diatoms (Beardall et al,, 1976). Simple diffusion from the algae might thus explain the abundance of glycine and serine, but not of glutamic acid. However, free amino acids were probably not lost from the algae by simple leakage as suggested by Mague et al. (1980). They found that the free intracellular amino acid pool in Skeletonema costatum differed considerably from the extracellular pool, though glutamic acid dominated both. Possibly, the extracellular amino acids are selectively lost from the algae, e.g. due to surplus production or to accumulation of specific amino acids as metabolic waste products. Comparison of intra- and extracellular amino acid pools during short incubation times with $\mathrm{H}^{14} \mathrm{CO}_{3}$ may elucidate the source of the extracellular pool.

\section{Release of DFAA from Ulva lactuca}

Among other primary producers in Kysing Fjord, the macrophyte Ulva lactuca, but occasionally also Chaetomorphasp. and Enteromorpha sp. are abundant in summer. Net release of DFAA from $U$. Iactuca caused a larger concentration increase in the dark than in the light in both filtered and unfiltered sea water (Fig. $7 \mathrm{~A}$ and $B$ ). Removal of bacteria by filtration of the water had apparently no effect in the light, but in the dark higher DFAA concentrations occurred in filtered water. The DFAA consisted mainly of glutamic acid, serine, alanine and glycine, while the dominant free extractable amino acids in $U$. lactuca was glutamate
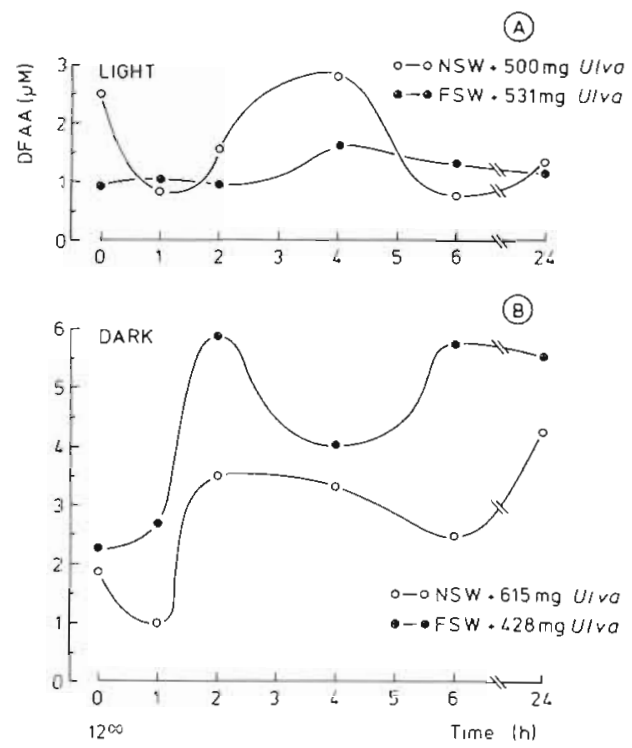

Fig. 7. Concentration of DFAA in natural sea water (NSW) or filtered sea water (FSW) with natural fragments of Ulva lactuca, in the light (A), or in the dark (B). Initial DFAA concentration: $0.917 \mu \mathrm{M} ; 16^{\circ} \mathrm{C}, 18 \% \mathrm{~S}$. Incubations started at 12.00 on 6 September 1980. Means of 2 samples of $40 \mathrm{ml}$ of sea water

which made up $54 \%$ of the extractable pool lown unpubl. obs.). Glutamate usually constituted from 5 to $10 \%$ of the DFAA in the incubation flasks. A similar proportion of glutamate occurred in the water before $U$. lactuca was added.

Marine macrophytes are reported to lose only small percentages of the fixed carbon as EOC (Brylinski, 
1977), but changes in physical conditions may influence the release (Sieburth, 1969). Various macroalgae collected in Kysing Fjord have previously been found to increase the ambient concentrations of free primary amines (Jørgensen, 1979). The specific processes leading to the present DFAA changes cannot be discerned from the results obtained. However, the results probably indicate that both release of organic substances and bacterial transformation of the organic matter were involved. The difference between the extractable and the extracellular amino acid pools, and the unchanged DFAA composition prior to and during the incubations suggest that DFAA were not lost by leage or diffusion from $U$. lactuca. The amino spectra rather suggest that DFAA were produced by the 'usual' DFAA contributors which simply have taken advantage of an increased substrate such as organic matter released from $U$. lactuca. Bacteria assimilating and transforming organic substances may be such contributors. The ambiguous effect of removal of bacteria from the incubation media does not contradict this postulate, since the bacteria probably have spread from the surface of $U$. lactuca to the surrounding water. The elevated dark concentrations may have been caused by a higher release during the non-photosynthetic period.

\section{Release of DFAA from Sediment}

Net release of amino acids from the sediment surface in the light and in the dark was 5.5 and $5.4 \mathrm{nmol}$ $\mathrm{cm}^{-2} \mathrm{~h}^{-1}$, respectively (Fig. 8). DFAA concentrations above dark-incubated sediment cores were less consistent than concentrations above the cores in the light. After an incubation time of $6 \mathrm{~h}$, the mean DFAA con- centration in the 'light' samples decreased, as compared with the 'dark' samples in which a slight increase was still observed by $24 \mathrm{~h}$. DFAA decline in the 'light' cores was probably caused by a higher amino acid assimilation by organisms inhabiting the sediment surface, relative to the 'dark' cores. Thus, for Kysing Fjord surface sediment more rapid uptake of glycine in the light than in the dark was demonstrated (Jørgensen et al., 1980). This may indicate that photosynthesis-dependent processes participate in amino acid reduction. Diatoms which are abundant in the surface sediment are possible utilizers of the amino acids; they are reported to utilize amino acids as nitrogen source during photosynthesis (North and Stephens, 1972).

Release within the initial $4 \mathrm{~h}$ corresponds to a net transport of $92 \mathrm{nmol}$ DFAA $\mathrm{I}^{-1} \mathrm{~h}^{-1}$ to the overlying water body, assuming an average water depth of $0.6 \mathrm{~m}$ in the estuary. In the incubations, the released amino acids were dominated by ornithine, leucine, and glutamic acid, but in some of the samples taurine made up more than $10 \%$. In minor concentrations ( $<50 \mathrm{nM}$ ) $\beta$-alanine and $\alpha$-ABA occurred in all samples.

The DFAA concentration in Kysing Fjord sediment porewater was 10 to 20 times higher than in the overlying water, with glutamic acid, serine, glycine, alanine, and ornithine being most abundant (Jørgensen et al., 1980). This concentration difference favours a diffusion from the sediment; amino acid flux may be further increased by active benthic infauna (Jorgensen et al., 1980). Ornithine, occasionally the dominant free amino acid in the water, was among the most abundant released amino acids in the present study. Ornithine (and taurine) may also be excreted from the sedimentinhabiting polychaete Nereis spp. (Jargensen and Kristensen, 1980).
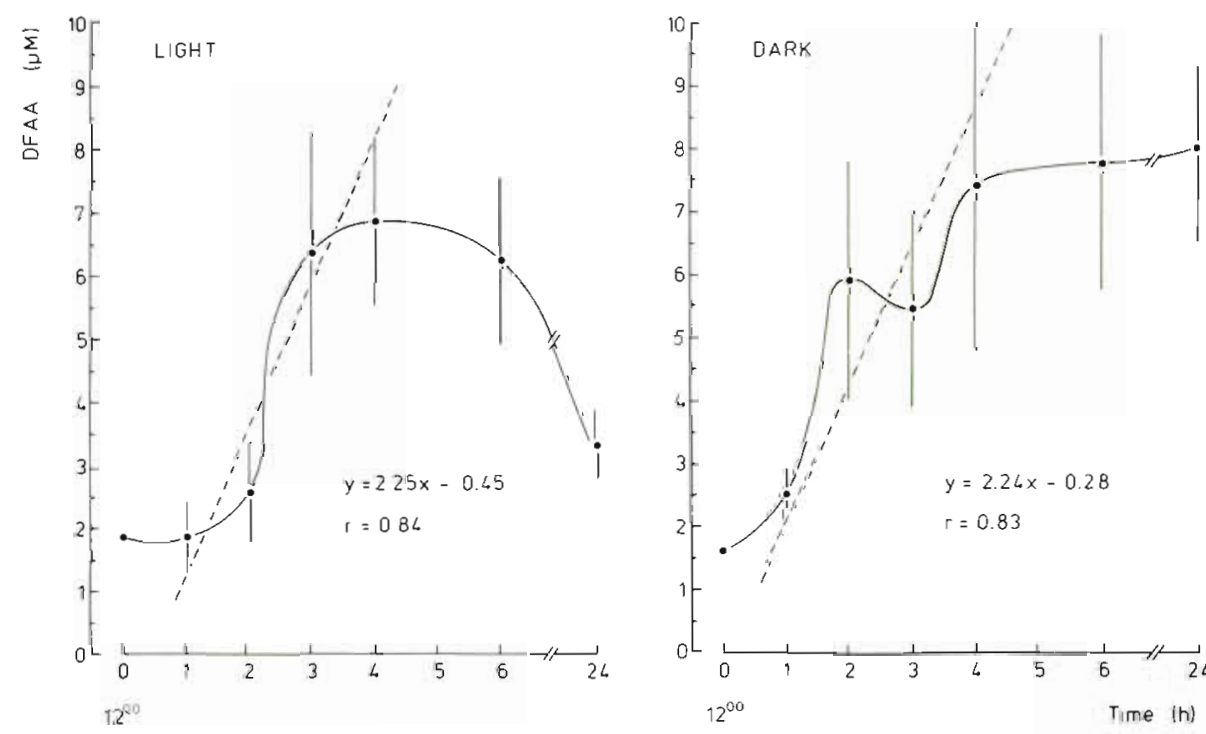

Fig. 8. Net release of DFAA from undisturbed sediment cores taken at Station 1 in Kysing Fjord. Concentration of DFAA in light and dark measured in $40 \mathrm{ml}$ natural sea water above sediment surface. Linear regressions calculated for initial $4 \mathrm{~h}$ concentration increase. Cores were incubated from 5 September 12.00 to 6 September $12.00 .16^{\circ} \mathrm{C}, 18 \% \mathrm{~S} ; \mathrm{n}=3$, means \pm 1 S.D. 
The amino acid release rate of $5.5 \mathrm{nmol} \mathrm{cm}^{-2} \mathrm{~h}^{-1}$ from the sediment surface was 5 times larger than the rate measured from a subtropical seagrass bed (Jørgensen et al., 1981b). The importance of release of organic nitrogen in the total nitrogen flux from the sediment was suggested by Nixon et al. (1976), who measured the annual inorganic nitrogen flux from the sediment in the Narrangansett Bay, Rhode Island. The present release rate of $92 \mathrm{nmol}^{-1} \mathrm{~h}^{-1}$ to the overlying water corresponds to a carbon flux of $4.8 \mu \mathrm{g} \mathrm{C}^{-1} \mathrm{~h}^{-1}$; this is a substantial amount as compared with the primary production rates of 2.1 to $21 \mu \mathrm{g} \mathrm{C}^{-1} \mathrm{~h}^{-1}$. DFAA release from the sediment probably explains the higher DFAA concentrations occasionally observed at low tides in the estuary.

\section{CONCLUSIONS}

In the Kysing Fjord estuary, heterotrophic and probably mainly microbial processes are tentatively concluded to be major producers of DFAA rather than direct release from the primary producers. Separation of EOC from phytoplankton thus suggested that released free amino acids constituted only up to $10 \%$ of ambient DFAA pools. Macrophytes such as U. lactuca may periodically contribute DFAA to the water, but the amino acids appeared not to originate as true exudate products. Release from sediment was apparently the most important single source of DFAA as indicated by the significant amino acid transport from the sediment surface. The microbial turnover rate of amino acids mainly depended on temperature and number of bacteria, but DFAA concentrations also influenced assimilation. Amino acid turnover was important in the carbon flux of the estuary. On 2 occasions, when a low primary production occurred, more carbon was fixed in amino acid assimilation than in phytoplankton production.

Acknowledgements. I wish to thank L. Cammen, J. Hylleberg, and $M$. Sondergaard for reading and criticizing the manuscript. The assistance of K. T. Jensen and H. R. Siegismund in collecting hydrographical data is sincerely acknowledged. A. Jensen provided chlorophyll data and E. Kristensen skillfully drafted the figures. This study was supported by grants from the University of Aarhus and the Danish Natural Science Research Council, No. 511-15884 (chromatographic equipment).

\section{LITERATURE CITED}

Beardall, J., Mukerji, D., Glover, H. E., Morris, I. (1976). The path of carbon in photosynthesis by marine phytoplankton. J. Phycol. 12: 409-417

Bohling, H. (1970). Untersuchungen über freie gelöste Aminosäuren in Meerwasser. Mar. Biol. 6: 213-225
Brylinski, M. (1977). Release of dissolved organic matter by some marine macrophytes. Mar. Biol. 39: 213-220

Crawford, C. C., Hobbie, J. E., Webb, K. L. (1974). The utilization of dissolved free amino acids by estuarine microorganisms. Ecology 55: 551-563

Dawson, R., Gocke, K. (1978). Heterotrophic activity in comparison to the free amino acid concentrations in Baltic Sea water samples. Oceanol. Acta 1: 45-54

Fattorusso, E., Piatelli, M. (1980). Amino acids from marine algae. In: Scheuer, P. J. (ed.) Marine natural products, Vol. III. Academic Press, New York, pp. 95-140

Gocke, K., Dawson, R., Leibezeit, G. (1981). Availability of dissolved free glucose to marine heterotrophs. Mar. Biol. 62: 209-216

Hagström, Å., Larsson, U., Hörstedt, P., Normark, S. (1979). Frequency of dividing cells, a new approach to the determination of bacterial growth rates in aquatic environments. Appl. environ. Microbiol. 37: 805-812

Helleburst, J. A. (1965). Excretion of some organic compounds by marine phytoplankton. Limnol. Oceanogr. 10: 192-206

Hobbie, J. E., Crawford, C. C., Webb, K. L. (1968). Amino acid flux in an estuary. Science, N.Y. 159: 1463-1464

Hobbie, J. E., Daley, R. J., Jasper, S. (1977). Use of nuclepore filters for counting bacteria by fluorescence microscopy. Appl. environ. Microbiol. 33: 1225-1228

Hodson, R. E., Azam, F., Carlucci, A. F., Fuhrman, J. A., Karl, D. M., Holm-Hansen, O. (1981). Microbial uptake of dissolved organic matter in McMurdo Sound, Antarctica. Mar. Biol. 61: 89-94

Jørgensen, N. O. G. (1979). Annual variation of dissolved free primary amines in estuarine water and sediment. Oecologia (Berl.) 40: 207-217

Jørgensen, N. O. G., Blackburn, H. T., Henriksen, K, Bay, D. (1981b). The importance of Posidonia oceanica and Cymodocea nodosa as contributors of free amino acids in water and sediment of seagrass beds. P.S.Z.N.I: Mar. Ecol. 2: $97-112$

Jorgensen, N. O. G., Kristensen, E. (1980). Uptake of amino acids by three species of Nereis (Annelida: Polychaeta). I. Transport kinetics and net uptake from natural concentrations. Mar. Ecol. Prog. Ser. 3: 329-340

Jørgensen, N. O. G., Lindroth, P., Mopper, K. (1981a). Extraction and distribution of free amino acids and ammonium in sediment interstitial waters from the Limfjord, Denmark. Oceanol. Acta 4: 465-474

Jørgensen, N. O. G., Mopper, K., Lindroth, P. (1980). Occurrence, origin, and assimilation of free amino acids in an estuarine environment. Ophelia 1 (Suppl.): 179-192

Kofoed, L. H. (1975). The feeding biology of Hydrobia ventrosa (Montagu). II. Allocation of the components of the carbon-budget and the significance of the secretion of dissolved organic material. J. exp. mar. Biol. Ecol. 19: 243-256

Lancelot, C. (1979). Gross excretion rates of natural marine phytoplankton and heterotrophic uptake of excreted products in the Southern North Sea, as determined by shortterm kinetics. Mar. Ecol. Prog. Ser. 1: 179-186

Larson, U., Hagström, $\AA$. (1979). Phytoplankton exudate release as an energy source for the growth of pelagic bacteria. Mar. Biol. 52: 199-206

Liebezeit, G. (1980). Aminosäuren und Zucker im marinen Milieu - neuere analytische Methoden und ihre Anwendung. Dissertation, Universität Kiel

Lindroth, P., Mopper, K. (1979). High performance liquid chromatography determination of subpicomole amounts of amino acids by precolumn fluorescence derivatization with o-phthaldialdehyde. Anal. Chem. 51: 353-383 
Lorenzen, C. J. (1967). Determination of chlorophyll and pheopigments: spectrophotometric equations. Limnol. Oceanogr. 12: 243-246

MacLeod, R. A. (1971). Bacteria, fungi and blue-green algae. In: Kinne, O. (ed.) Marine ecology, Vol. I, Environmental factors, Part 2. Wiley, London, pp. 689-703

Mague, T H., Friberg, E., Hughes, D. J., Morris, I. (1980). Extracellular release of carbon by marine phytoplankton; a physiological approach. Limnol. Oceanogr. 25 (2): 262-279

Menzel, D. W., Ryther, J. H. (1970). Distribution and cycling of organic matter in the oceans. In: Wood, D. H. (ed.) Symposium on organic matter in natural waters. University of Alaska, Alaska, Occ. Publ. 1: 31-54

Murphy, I., Riley, T. P. (1962). A modified single solution method for the determination of phosphate in natural waters. Anal. Chim. Acta 27: 21-26

Muus, B. (1967). The fauna of Danish estuaries and lagoons. Meddr Kommn Danm. Fisk.-og Havunders. 5: 1-316

Nalewajko, C., Dunstall, T. G., Shear, H. (1976). Kinetics of extracellular release in axenic algae and in mixed algalbacterial cultures: significance in estimation of total (gross) phytoplankton excretion rates. J. Phycol. 12: 1-5

Nixon, S. W., Oviat, C. A., Hale, S. S. (1976). Nitrogen regeneration and metabolism of coastal marine bottom communities. University of Rhode Island Marine Reprint 77 : 269-283

North, B. B., Stephens, G. C. (1972). Amino acid transport in Nitzschia ovalis Arnott. J. Phycol. 8: 64-68

Riley, J. P., Segar, D. A. (1970). The seasonal variation of the free and combined dissolved amino acids in the Irish Sea. J. mar. biol. Ass. U.K. 50: 713-720
Schell, D. M. (1974). Uptake and regeneration of free amino acids in marine waters of the Southeast Alaska. Limnol. Oceanogr. 19 (2): 260-270

Sieburth, J. M. (1969). Studies on algal substances in the sea. III. The production of extracellular organic matter by littoral marine algae. J. exp. mar. Biol. Ecol. 3: 290-309

Solorzano, L. (1969). Determination of ammonia in natural waters by the phenolhypochlorite method. Limnol. Oceanogr. 14: 799-810

Thomas, J. P. (1971). Release of dissolved organic matter from natural populations of marine phytoplankton. Mar. Biol. 11: $311-323$

Williams, P. J. Le B., Berman, T., Holm-Hansen, O. (1976). Amino acid uptake and respiration by marine heterotrophs. Mar. Biol. 35: 41-47

Williams, P. J. Le B., Yentsch, C. S. (1976). An examination of photosynthetic production, excretion of photosynthetic products, and heterotrophic utilization of dissolved organic compounds with reference to results from a coastal subtropical sea. Mar. Biol. 35: 31-40

Williams, P. M., Oeschger, H., Kinney, P. (1969). Natural radiocarbon activity of the dissolved organic carbon in the North-east Pacific Ocean. Nature, Lond. 224: 256-258

Wood, L. (1966). Determination of free amino acids in seawater. In: Scova, N.B., et al. (eds.) Automation in analytical chemistry. Technicon symposium. Mediad Inc., New York, pp. $625-655$

Wood, E. D., Armstrong, F. A. J., Richards, F. A. (1967). Determination of nitrate in sea water by cadmium-copper reduction to nitrite. J. mar. biol. Ass. U.K. 47 23-31

This paper was submitted to the editor; it was accepted for printing on February 4, 1982 